\title{
THE ANALYSIS OF ENDHOPORIC REFERENCE IN OPRAH'S INSPIRATIONAL GOLDEN GLOBAL SPEECH
}

\author{
Renny Andriani' ${ }^{1}$, Nai Supartini² \\ ${ }^{1}$ IKIP Siliwangi \\ ${ }^{2}$ IKIP Siliwangi \\ ${ }^{1}$ rennyandriani@student.ikipsiliwangi.ac.id, ${ }^{2}$ naisupartini@ikipsiliwangi.ac.id
}

\begin{abstract}
Communication through speaking is useful to convey what we mean to the listener. The aim of the research is to know endhoporic reference in Oprah's speech. This research use descriptive qualitative method. The writer choose a transcript about Oprah's speech from the website Endophoric is diveded in two types, there are anaphoric and cataphoric. The result shows that endhoporic references can be found in each paragraph in Oprah's speech. This research found that anaphoric predominate in Oprah's speech because she refers to something that has mentioned at before. In this study there were six sentences that referred to anaphoric reference and only one sentence referred to the cathaporic reference. Anaphoric is the only reference related to cohesion.
\end{abstract}

Keywords: Cohesion, Reference, Endhoporic

\section{INTRODUCTION}

Language is a communication tool for human. Communication through speaking is useful to convey what we mean to the listener. Communication as the implementation of language as a means of regulating affairs (Parmawati, 2018). Language has a system and rule called grammar. It is imperative because with grammar we can understand a language easier. Based on Lado (1975) cited in (Bäuerle et al., 2012) grammar is a rule in language that aims to tell the right way to use language. However in grammar greater recognition on the formal properties of language rather than the meaning of the language (Coulthard, 1992).

Fortunately, studies that explain how language relations and their context are called discourse analysis (McCarthy, 1991). This study focuses on how the use of language and divided into two types, namely written and spoken (Khalifah et al., 2019). Based on explanation it's means the unit that exists in text and relates the meaning of words called Cohesion. Coherence refers to the relationship that underlines the text which lies in how people interpret the text itself (Ngunyen, 2018). Halliday \& Hasan (1976) as cited in (Bahaziq, 2016) state that the semantic relationship from one element to another inside the textual content is known as cohesion. Cohesion not always focuses on grammar but also on vocabulary. Grammatically, cohesive device consist of lexical cohesion, conjuction, substitution, ellipsis and reference. In this research focus on reference.

References enter the type of cohesion which refers to other language(Emilia et al., 2018). Based on (Bloor \& Bloor, 2013) reference is diveded in endhoporic and exophoric. To get an exophoric references, the reader can find it outside the text in an immediate environment with the reader and writer (Bahaziq, 2016). It is due to the fact endophoric can be found in the textual content itself. Endophoric is diveded in two types, anaphoric and cataphoric. Anaphoric is a reference that regarding to something that has appeared at a previous point 
(Akogbeto, 2017). The example is "father asked Dodi to make a coffee, therefore he make a cofee". Cataphoric reference or forward the opposite of anaphoric which refers to the words that have been mentioned later. The example is" my siter like to play a doll, Tia like it a doll".

Previous authors who have successfully analyzed endophoric references, One of them is belong to (Khalifah et al., 2019) entitled "An analysis of Endhporic Reference Cohesion Device in Mark Zuckeberg Biography". This research tried to investigates kinds of endhoporic reference in biography. Another research conducted by (Bahaziq, 2016) that analysis of cohesion device in a Student's Essay Writing English Language Teaching.

In this research, the researcher also interest to use endhoporic reference to analyze Oprah inspirational global speech that has a purpose to investigate use of endhoporic reference of Oprah's speech and to know the most dominant reference uses. The title of this research is The Analysis of Endhoporic Reference in Oprah's Inspirational Golden Global Speech.

\section{METHOD}

Qualitative method was employed in this research in order to analysis reference in Oprah Inspirational Golden Global speech. Based on Creswell cited in (Aryana.S \& Apsari.Y, 2018) that "Analyzing qualitative data requires understanding how to make sense of text and image, so that you can form answers to your research questions ". The researcher using qualitative design is to make reader easy to know what the meaning in article.

The steps of collecting data are as follows, The writer choose a transcript about Oprah's speech from the website (Friedman, 2018) consist of 976 words (in eight minutes video). Oprah Winfrey was the recipient of the Golden Globes' annual Cecil B. DeMille award on seventh january 2018 for lifetime achievement, she gave a powerful acceptance speech during Sunday night's ceremony.Second, the writer read the transcript as the data for this research repeatedly. Third, the writer marked the words include into endophoric reference. Fourth the writer catagorized the data into anaphoric or cataphoric. Last, put all of the data in the table then gave the explanation.

\section{RESULTS AND DISCUSSION}

\section{Results}

Table 1. Analysis reference in Oprah's speech.

\begin{tabular}{|c|c|c|}
\hline Utterance & Reference & Reason \\
\hline $\begin{array}{l}\text { I was a little girl ... } \\
\text { Anne watching } \\
\text { Anne Bancroft ... Academy } \\
\text { Awards. She opened ... Sidney } \\
\text { Poitier." }\end{array}$ & Anaphoric & $\begin{array}{l}\text { In this sentence, "she" is } \\
\text { anaphoric which refers to } \\
\text { 'Anne Bancorft'. The } \\
\text { reason is that if there is no } \\
\text { presuppossed clause "my } \\
\text { mother's house... } \\
\text { Academy Awards" we } \\
\text { cannot decide what 'she' } \\
\text { refer to. It is because we } \\
\text { need to look back at the } \\
\text { sentence before. }\end{array}$ \\
\hline $\begin{array}{l}\text { The winner is Sidney Poitier." } \\
\text { Up to the stage came the most } \\
\text { elegant man I ever remembered. }\end{array}$ & Anaphoric & $\begin{array}{l}\text { In this sentence, "Elegant } \\
\text { man", "His", and "a black } \\
\text { man" is anaphoric which }\end{array}$ \\
\hline
\end{tabular}




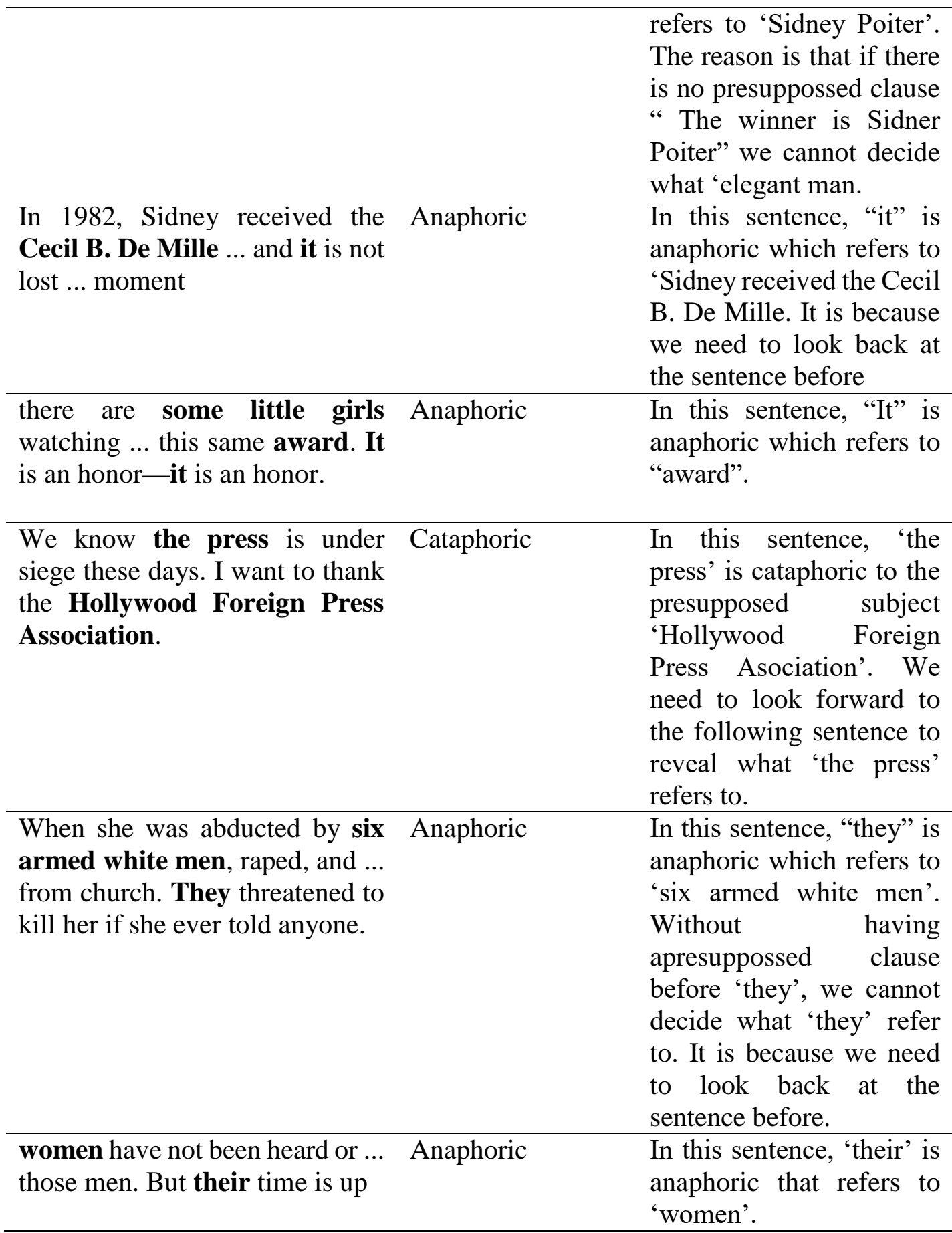

The result showed six sentences that use anaphoric and one sentence use cathaporic. The researcher can found the reference in every paragraph from the transcript text.

\section{CONCLUSION}

Based on the findings and discussion, the researcher found an endhoporic reference in each paragraph. Anaphorical references dominate in Oprah's speech. Based on Halliday and Hasan (1976) as quoted by (Akogbeto, 2017) in cohesion the type of reference related to cohesion is only this anaphoric reference because anaphorists provide links with their predecessors whereas cataphorics are not related because they provide links afterwards. 


\section{ACKNOWLEDGMENTS}

Thank you to Allah, for giving me blessings on health or other things, so that I can complete this research. Thanks to friends who also helped affectionately provided input for my article. Thank you also to Nai Supartini Atmawidjaja, S.S., M.Hum as the supervisor of article writing to make this article better.

\section{REFERENCES}

Akogbeto, P. (2017). Cohesion in texts : A Discourse Analysis Approach to Newspaper Article. Revue Du Cames, Litterature, Languages et Linguistique.

Aryana, S., \& Apsari, Y. (2018). Analysing Teacher's Difficulties In Teaching Listening. Eltin Journal, Journal Of English Language Teaching In Indonesia, 6(2), 100-106.

Bahaziq, A. (2016). Cohesive Devices in Written Discourse: A Discourse Analysis of a Student's Essay Writing. English Language Teaching, 9(7), 112.

Bäuerle, R., Schwarze, C., \& Stechow, A. von. (2012). Meaning, Use, and Interpretation of Language. Walter de Gruyter.

Bloor, T., \& Bloor, M. (2013). The Functional Analysis of English: A Hallidayan Approach (3rd ed.). Routledge.

Coulthard, M. (1992). An Introduction to Discourse Analysis (T. \& F. E-library (ed.); First edit). Routlege.

Emilia, E., Habibi, N., \& Bangga, L. A. (2018). An anlysis of cohesion of exposition texts: An Indonesian context. Indonesian Journal of Applied Linguistics, 7(3), 515-523.

Friedman, M. (2018). Here's the Full Transcript of Oprah's Inspirational Golden Globes Speech. Harper's Bazaar.

Khalifah, M. S., Wibowo, J. C., \& Rachmijati, C. (2019). an Analysis of Endophoric Reference Cohesion Devices in Mark Zuckerberg Biography. PROJECT (Professional Journal of English Education), 2(2), 222.

McCarthy, M. (1991). Discourse Analysis for Language Teachers (M. Swan (ed.)). Cambridge University Press.

Parmawati, A. (2018). Using Analytic Teams Technique to Improve Students' Speaking Skill. Edulitics (Education, Literature, and Linguistics) Journal, 3(2), 21-25. 